\title{
KEKUATAN MEDIA BARU YOUTUBE DALAM MEMBENTUK BUDAYA POPULER
}

\author{
Detya Wiryany ${ }^{1}$, Tiarani Vidia Pratami ${ }^{2}$ \\ Program Studi Ilmu Komunikasi Universitas Informatika Dan Bisnis Indonesia \\ Email : detyawiryany@unibi.ac.id, tiaranividiapratami2199@gmail.com
}

\begin{abstract}
Abstrak
Teknologi tidak ada hentinya untuk terus berkembang, dengan perkembangan dari teknologi itu sendiri melahirkan new media dimana salah satunya adalah Youtube. Youtube merupakan sosial media yang sedang berada dipuncak kejayaannya pada massa sekarang. Budaya populer lahir dari youtube dengan begitu cepat tanpa melihat golongan masyarakat. Teori Difusi Inovasi yang dikembangkan oleh Everett Rogers memaparkan bagaimana sebuah ide dan teknologi baru tersebar dalam sebuah kebudayaan. Pada dasarnya Teori Difusi Inovasi menjelaskan proses bagaimana suatu inovasi disampaikan melalui saluran-saluran tertentu sepanjang waktu kepada sekelompok anggota dari seistem sosial. Dampak paling nyata yang dapat kita lihat saat ini adalah banyaknya artis yang lahir dari youtube.
\end{abstract}

\section{Kata kunci : kekuatan New Media, Budaya Populer, Youtube}

\begin{abstract}
Technology has never ceased to grow through time. The development itself giving a chance to new media such as Youtube to grow rapidly. Youtube is one of the largest social media that we had now. Popular culture was born from YouTube, and it's so quickly spread by anyone who does. The Innovation Diffusion Theory developed by Everett Rogers describes how new ideas and technologies spread in culture. Basically, the Innovation Diffusion Theory explains the process of how innovation is delivered through certain channels all the time to the people from the social system. The most obvious impact that we can see today was the number of famous people that came from YouTube.
\end{abstract}

\section{Keyword: The power of new media, popular culture, YouTube}

\section{PENDAHULUAN}

Youtube adalah sebuah situs website dimana memiliki tujuan untuk memfasilitasi penggunanya untuk berbagi video yang mereka miliki, atau hanya sekedar menonton dan menikmati video. Youtube memiliki manfaat, diantaranya adalah untuk mencari video klip music, short movie, acara televise, trailer film, video pembelajaran dan lain sebagainya, yang merupakan karya dari pihak tertentu. Ron Rice mendefinisikan bahwa media baru sebagai teknologi komunikasi yang melibatkan komputer didalamnya (baik mainframe, $\mathrm{PC}$, maupun notebook) yang memfasilitasi penggunanya untuk berinteraksi antar sesama pengguna ataupun dengan informasi yang diinginkannya.
Youtube merupakan new media (media baru) yang terlahir dari evolusi teknologi. Teknologi tidak pernah bosan untuk terus berkembang dan berevolusi, revolusi komunikasi merupakan bagian dari sebuah rangkaian perubahan cara-cara berkomunikasi yang telah berjalan dalam history kehidupan manusia. Perubahan yang terjadi merupakan konsekuensi yang di tempa oleh bidang sosial, ekonomi, politik, kultural dan gaya hidup manusia. Dari hasil wawancara yang dilakukan penulis, di tahun 2015 hingga sekarang adalah massa kejayaan bagi youtube, yang artinya youtube berada dalam urutan nomor 1 penggunaan sosial media dimasyarakat seluruh dunia.

Seluruh lapisan masyarakan saat ini banyak yang mengakses youtube. sebagian 
masyarakat dunia ada yang menganggap bahwa youtube adalah sarana untuk menyalurkan bakat, namun ada juga sebagian masyarakat yang beranggapan bahwa youtube adalah ajang unjuk kreativitas dari masing-masing orang. Pendapat khalayak perihal youtube berbeda-beda karena fungsi utama dari youtube ini adalah mengaplikasikan suatu objek agar dapat disaksiakan oleh para pengguna media diseluruh dunia. Karya yang di upload ke youtube akan menghasilkan uang jutaan bahkan miliaran rupiah, baik dari iklan yang dipasang di setiap video atau jumlah subscriber yang dimiliki. Kemudahan mengakses dan menguplod berbagai video menjadikan warganet (warga internet) berlomba-lomba untuk meraup keuntungan dari hasil kreativitas mereka yang diupload ke youtube.

Hal tersebut merupakan fenomena nyata dimana youtube menjadi bagian dari kehidupan masyarakat milenial pada masa kini. Pada teori Difusi inovasi dijelaskan tentang bagaimana ide dan teknologi baru tersebar dan membentuk kebudayaan. Teori yang dipopulerkan oleh Everett Rogers pada tahun 1964 melalui buku yang berjudul Diffusion of Innovations. Rogers mendefinisikan difusi adalah sebuah inovasi yang di komunikasikan melalui berbagai saluran dan jangka waktu tertentu dalam sebuah sistem sosial. ${ }^{1}$ Perubahan ini tidak hanya terjadi pada perlilaku individu saja, melainkan terhadap suatu kelompok atau komunitas masyarakat yang kemudian menjadi sebuah budaya populer. Semakin banyak yang mengunggah video di youtube semakin beragam pula konten yang ada. Tidak jarang seseorang menjadi idola karena konten yang dia buat sangat menarik, lahirnya seorang idola tidak jarang akan mempengaruhi perilaku yang menjadi penggemarnya.

Berdasarkan penejelasan menarik di atas itulah, yang menjadi alasan penulis untuk meneliti bagaimana kekuatan youtube dapat mempengaruhi dan membentuk budaya baru masyarakat. Oleh karena itu, penulis melakukan kajian tentang Kekuatan media baru youtube dalam membentuk budaya populer.

\subsection{Tujuan dari Penelitian}

\footnotetext{
${ }^{1}$ www.ejournal.ilkom.fisip-unmul.ac.id akses 5 oktober 2019 pukul 12.00
}

Tujuan penelitian ini adalah untuk mengetahui kekuatan youtube dalam mempengaruhi dan membentuk budaya popular.

\subsection{Manfaat dari Penelitian}

Manfaat dari penelitian ini diharapkan dapat memberikan manfaat di kemudian hari bagi penulis khususnya dan bagi pihak yang akan menggunkaan tulisan ini sebagian tambahan kasanah ilmu umumnya.

\section{TINJAUAN PUSTAKA}

\subsection{Pengertian Komunkasi Massa}

Menurut Bitner (Rakhmat, 2003:188) komunikasi massa adalah pesan yang dikomuniasikan melalui media massa pada sejumlah besar orang (mass communication is message communicated through a mass medium to a large number of people) dari definisi tersebut dapat dapat disimpulkan bahwa komunikasi massa wajib menggunakan media massa sebagai channel nya agar bisa disebut komunikasi massa. media yang termasuk media komunikasi elektronik adalah televisi dan radio, dan surat kabar serta majalah disebut dengan media cetak.

Pengertian komunikasi massa menurut Gerbner (1967) "mass communication is the tehnologically and institutionally bassed production and distribution of the most broadly shared countinuous flow of messages in industrial societies" komunikasi massa adalah produksi dan distribusi yang berlandaskan teknologi dan lembaga dari arus pesan yang kontinyu serta paling luas dimiliki orang dalam masyarakat industri (Rakhmat 2003:188).

Dari dua definisi diatas dapat ditarik kesimpulan bahwa komunikasi massa adalah komunikasi yang disampaikan melalui media massa yang menghasilkan sebuah produk berupa pesan-pesan komunikasi. Produksi tersebut disebarkan kepada khalayak secara terus menerus dalam kurun waktu yang tentu, misal harian, minguan dan seterusnya.

\subsection{Ciri-Ciri Komunikasi Massa}


Sedangkan ciri-ciri komunikasi massa, menurut Elizabeth Noelle Neumann adalah sebagian berikut :

1. Bersifat tidak langsung, artinya harus melalui media teknis.

2. Bersifat satu arah, artinya tidak ada interaksi antara peserta-peserta komunikasi.

3. Bersifat terbuka, artinya ditujukan pada publik yang tidak terbatas atau anonym.

4. Mempunyai publik yang tersebar.

\subsection{New Media}

Menurut buku komunikasi massa, yang menjadi ciri utama dari media baru adalah adanya akses keterhubungan antara individu sebagai penerima maupun pengirim pesan. Karakteristik dari media baru adalah terbuka dan universal.

Ron Rice mendefinisikan bahwa media baru sebagai teknologi komunikasi yang melibatkan computer didalamnya (baik mainframe, PC, maupun notebook) yang memfasilitasi penggunanya untuk berinteraksi antar sesama pengguna ataupun dengan informasi yang diinginkannya.

Kekuatan new media yaitu Multimedia include audio, video, image, dengan berbagai efek yang sangat memanjakan mata dan telinga, Sangat-sangat interaktif Sangat-sangat portable, baik waktu penggunaan, pilihan konten, segmentasi penggunaan, dll. Dapat menjadi lahan pekerjaan. Dapat menjadi lahan eksistensi Dapat menjadi lahan berkreatifitas Media interaktif memiliki unsur audio-visual (termasuk animasi) dan disebut interaktif karena media ini dirancang dengan respon pemakai secara aktif.

\subsection{Manfaat New Media}

Dari penjelasan New Media diatas maka dapat diketahui New Media memiliki beberapa manfaat sebagai berikut :

a. Arus informasi yang dapat dengan mudah dan cepat diakses dimana saja dan kapan saja.

b. Sebagai media transaksi jual beli.

c. Sebagai media hiburan contohnya game online, jejaring sosial, streaming video dll.

d. Sebagai media komunikasi yang efisien.
Berikut disampaikan juga beberapa kekurangan dari New Media yaitu sebagai berikut:

a. Terbukanya informasi menimbulkan kemungkinan pencurian data pribadi. Hal ini bisa dilakukan hacker dengan tujuantujuan tertentu.

b. Virus. Terbukanya arus informasi dan komunikasi juga dapat membawa virus yang berkedok aplikasi dengan mudah menyebar.

c. Rasa ketagihan berlebihan, contohnya pada saat bermain game online atau jejaring sosial.

\subsection{YouTube}

Youtube adalah portal atau situs video sharing milik google Inc. Youtube merupakan situs terbesar didunia maya. Youtube merupakan salah satu dari banyak sosial media yang masuk kedalam kategori media baru. Jutaan video tersedia lengkap dan bisa dilihat secara gratis. Mulai dari video amatir karya pengguna youtube yang di upload, sampai dengan video-video karya produsen industri musik dunia tersedia diportal youtube ini.

Era internet video memang sedang berada dipuncaknya. Khalayak media cenderung lebih tertarik untuk mendapatkan beragam informasi, baik itu berita ataupun hiburan, lebih asik dilihat dalam bentuk video, karena lebih mudah dipahami dan lebih mampu untuk menggambarkan kondisi, emosi dan cerita dengan lebih simple dibandingkan format tulisan.

Berikut ini adalah kelebihan dan kekurangan youtube :

a. Kelebihan

1. Memudahkan pengguna untuk mencari suatu hal yang dibutuhkan dengan hanya mengitik satu kata kunci, kemudian akan muncul banyak hal yang berkaitan dengan kata kunci tersebut.

2. Konten di youtube lebih beragam dibandingkan media baru yang lain seperti instgram, facebook, twitter dan sebaginya. Hal ini dikarenakan youtube memiliki ruang pemutaran video atau audio lebih besar dibandingkan media baru yang lainnya.

3. Youtube sebagai sarana belajar otodidak. Banyak sekali faktor yang menghambat 
seseorang dalam menggali potensi dirinya, mulai dari keterbtasan biaya, waktu, dan tempat. Namun, dengan hadirnya youtube bisa mempermudah seseorang dalam menggali suatu hal seperti cara bermain gitar, cara memasak, cara bisa beatbox, dan sebagainya. Semua bakat dan potensi bisa diasah sendiri dengan menonton tutorialnya di youtube.

b. Kekurangan

1. Kebebasan mengakses video atau konten-konten berbau asusila, kekerasan atau hal yang mengandung unsur sara. Bagi anak dibawah umur (4-16 tahun ) hal tersebut sangan tidak dianjurkan.

2. Lahirnya berita bohong yang mengundang konflik. Seperti yang viral baru-baru ini yaitu, video seorang mahasiswa yang kepalanya berdarah pada salah satu aksi mahasiswa tahun 2018, dan dibagikan berulang kali sehingga viral di 2019 pada saat demo mahasiswa 2019 perihal tolak RUUKUHP dan RUU KPK. Dengan berita "mahasiswa dipukuli oknum polisi".

3. Semakin beragamnya youtube maka akan semakin menggeser televisi.

\subsection{Budaya Populer}

Budaya popular merupakan budaya yang lahir karena adanya media. Artinya, jika media dapat memproduksi sebuah budaya baru, maka pengaruh media akan sangat besar untuk diserap oleh publik hingga menjadikannya sebagai sebuah bentuk kebudayaan. Popular tidak terlepas dari perilaku konsumsi dan determinasi media massa terhadap public yangbertindak sebagai konsumen (Strinati, 2003)

Budaya populer menurut Frankfur, adalah budaya massa yang dihasilkan industri budaya untuk stabilitas maupun kesinambungan kapitalisme. Sedangkan menurut Williams (1983) mendefinisikan kata "populer" menjadi empat pengertian yaitu (1) banyak disukai orang; (2) jenis kerja rendahan; (3) karya yang dilakukan untuk menyenangkan orang; (4)budaya yang memang dibuat oleh orang untuk dirinya sendiri. ${ }^{2}$

\subsection{Ciri-Ciri Budaya Populer}

1. Komodifikasi, berubahnya nilai guna menjadi nilai tukar.

2. Tren, merupakan salah satu ciri sebuah budaya akan diikuti atau disukai banyak orang yang memungkinkan menjadi budaya populer.

3. Keseragaman bentuk, dimana budaya popular akan diikuti oleh masyarakat lainnya yang menjadi trand tersebut yang akhirnya hal tersebut akan memungkinkan orang lain untuk menjiplak. Penjiplak karya tersebut bisa menjadi pionir bagi karya lain yang berarti sama. Contoh : drama korea sukses besar di korea sendiri dan dinegara asia lainnya termasuk Indonesia. Akibatnya banyak sinetron Indonesia yang ceritanya mengadaptasi serial drama korea.

4. Adoptabilitas, budaya populer dapat beradaptasi oleh lingkungan.

5. Durabilitas, seberapa lama budaya populer itu bertahan.

6. Profabilitas, dilihat dari sisi ekonomi, budaya populer berpotensi menghasilkan keuntungan yang besar bagi industri yang mendukungnya.

\subsection{Teori Difusi Inovasi}

Difusi inovasi merupakan teori tentang bagaimana sebuah ide dan teknologi baru tersebar dalam sebuah kebudayaan. Teori ini dipopulerkan oleh Everett Rogers pada tahun 1964 melalui bukunya yang berjudul Diffusion of innovations. Ia mendefinisikan difusi adalah sebuah proses dimana sebuah inovasi dikomunikasikan melalui berbagai saluran dan jangka waktu tertentu dalam sebuah sistem sosial.

Untuk lebih jelasnnya lagi bahwa difusi adalah bentuk komunikasi yang memiliki sifat khusus dimana sifat tersebut berkaitan dengan pesan-pesan berupa gagasan baru, dimana pesanpesan tersebut disampaikan melalui saluran tertentu sepanjang waktu dan sekelompok anggota dari sitem sosial.

Jadi, dari penjelasan Rogers diatas terdapat kata kunci yang didapat yaitu inovasi, saluran

\footnotetext{
${ }^{2}$ www.ejournal.ilkom.fisip-unmul.ac.id akses 5 oktober 2019 pukul 12.00
} 
komunikasi, jangka waktu, system sosial. Dimana suatu inovasi yang disampaikan harus melalui saluran komunikasi disesuaikan dengan kebutuhan baik melalui media massa atau interpersonal dan semua itu ditujukan kepada masyarakat (sistem sosial). Namun masyarakat yang menjadi sasaran dari inovasi tersebut memiliki jangka waktu untuk memproses keputusan, apakah akan di terima atau ditolak. Berikut ini adalah penjelasan kata kunci yang didapat dari pemikiran Rogers :

a. Inovasi merupakan gagasan atau tindakan yang dianggap baru oleh seseorang, sesuatu yang disebut inovasi adalah yang dianggap baru oleh orang yang menerimannya. Dan konsep 'baru' dalam inovasi tidak harus selalu benar-benar baru.

b. Saluran komunikasi adalah alat yang digunakan untuk menyampaikan pesan dari yang memberi inovasi kepada penerima. Saluran komunikasi di tentukan sesuai kebutuhan bisa dengan media massa atau bahkan secara interpersonal. Semua itu tergantung kepada tujuan dari komunikasi tersebut.

c. Jangka waktu ialah sebuah proses dimana seseorang mengambil keputusan dari sebuah inovasi yang diperoleh apakah akan diterima atau tidak. Tentunya dalam proses tersebut melibatkan ruang dan waktu.

d. Sistem sosial yaitu sekumpulan unit yang berbeda secara fungsional dan terikat dalam kerjasama untuk memecahkan masalah dalam rangka mencapai tujuan bersama.

\section{HASIL DAN PEMBAHASAN}

a. Lahirnya budaya baru dikalangan masyarakat karena youtube

Saat ini youtube telah menjelma menjadi media utama (primary) bagi masyarakat, khususnya bagi masyarakat informasi, youtube tidak hanya menjadi lifestyle, tetapi menjadi kiblat sekaligus agen perubahan bagi seluruh lapisan masyarakat. Jika facebook sangat Berjaya di tahun 2005-2010, 2015sekarang adalah massa kejayaan Youtube, jika facebook lebih di dominasi oleh konten hiburan, yotube memberikan opsi yang lebih beragam dan variatif. Itulah yang menjadikan yotube lebih maju dibandingkan facebook, dan sekarang youtube pun sudah menggeser peran dari media massa tradisional seperti televisi, radio, koran dan lain-lain.

Youtube menjadi acuan dan kiblat untuk menentukan pandangan dan budaya mesyarakat saat ini, siapapun yang terlibat dan populer di youtube akan menjadi panutan mengalahkan kepopuleran selebritas pada media-media tradisional. Saat ini banyak budaya yang lahir dari youtube, dan ketergantungan masyarakat pada youtube sudah merambah keseluruh kalangan, dari anak-anak sampai orangtua, sehingga sangat mudah mempengaruhi perubahan-perubahan budaya pada masyarakat.

b. Kekuatan youtube dalam membentuk budaya populer

Menurut hasil wawancara yang penulis peroleh Kekuatan yang dimiliki youtube dalam membentuk budaya populer, sebenarnya adalah kekuatan dari New Media itu sendiri secara keseluruhan yaitu :

1. Multimedia include audio, video, image, dengan berbagai efek yang sangat memanjakan mata dan telinga.

2. Sangat-sangat interaktif

3. Sangat-sangat portable, baik waktu penggunaan, pilihan konten, segmentasi penggunaan, dll.

4. Dapat menjadi lahan pekerjaan.

5. Dapat menjadi lahan eksistensi

6. Dapat menjadi lahan berkreatifitas.

Youtube, facebook, Instagram dan new media yang lainnya pun memiliki kesempatan yang sama berada dipuncak kejayaan layaknya youtube tidak menutup kemungkinan. Namun faktor yang mempengaruhi yang paling utama itu adalah khalayak media cyber nya itu sendiri.

\section{Analisis kritis}

Analisis kritis dalam fenomena yang telah terjadi di masyarakat dengan melihat dari kekuatan youtube sebagai pembentuk budaya populer adalah contoh kasus yang ada di Indonesia, konstruksi sosial melalui media baru youtube, terlihat dari dari munculnya artis dadakan seperti Lucinta luna yang tiba-tiba populer karena wajahnya yang cantik seperti Barbie dan tubuhnya yang sangat sexy namun memiliki fakta bahwa dia adalah transgender, dan fakta bahawa dia adalah seorang laki-laki tersebut yang menjadikannya populer, karena itu semua tersebar di youtube, di youtube tersebar video 
dirinya sedang melakukan oprasi kelamin, dengan fakta-fakta yang muncul dan simpang siur, menjadikan media tradisional berbondongbondong untuk mewawancarai Lucinta Luna, sehingga itu membuat Lucinta luna semakin populer. Namun, jika di analisis kembali tidak seharusnya Lucinta luna populer pada waktu itu, karena dia lebih mengumbar sensasi daripada karya nya dijagat hiburan. Namun sekarang Lucinta Luna lebih baik lagi, karena kepopulerannya harus dipertanggung jawabkan oleh karena itu dia mulai berkarya dengan mengeluarkan single lagu nya yang berjudul 'bobo dimana' dan 'cinta tanpa status'. Terbukti bahwa Budaya populer tidak hanya mengubah sikap khalayak tetapi juga bisa mengubah orang yang mempengaruhi khalayak tersebut.

Contoh kasus kedua adalah lahirnya seorang miliyader muda yaitu Atta Halilintar. Awal dari kepopulerannya adalah viral di media baru youtube sebuah keluarga yang disebut dengan Gen Halilintar, dengan 11 anak yang pandai bernyanyi dan pintar berbahasa inggris. Video bakat dari anak-anak Gen Halilintar ini di Upload ke youtube dengan tujuan untuk sekedar menyalurkan bakat saja, namun menjadi viral karena keunikannya. Disanalah awal Atta membuat channel youtube sendiri dan membuat konten-konten menarik. Dengan gaya yang khas yaitu rambut berganti-ganti warna dan ikat kepala yang selalu ia kenakan menjadi trend masa kini bagi anak-anak remaja. Dengan ketenaran tersebut atta menjadi youtuber nomor 1 di asia tenggara, dengan jumlah subscriber lebih dari 16 juta.

\section{KESIMPULAN}

Kekuatan New Media dalam membentuk budaya populer dimasyarakat ialah karena kekuatan media itu sendiri, tidak pernah ada budaya yang populer tanpa dibantu oleh sebuah media. Dan, budaya populer yang tercipta merupakan kehendak dari media itu sendiri.

\section{REFERENSI}

Nuruddin, 2007. Pengantar Komunikasi Massa, Jakarta: PT. Raja Grafindo Persada.

Rinawati, Rini. 2013. Lifestyle Muslimah://mediator.fikom.unisba.ac.id/inde x.php/mediator/article/viewFile/58/52

(Akses 13 April 2015.)

https://www.google.com/url?sa=t\&source=web\& rct=j\&url=https://media.neliti.com/media/pu blications/93363-ID-pengaruh-konten-vlogdalam-youtubeterha.pdf\&ved=2ahUKEwiVnI_YyqflAhWE 6XMBHSPKC9AQFjABegQICRAN\&usg= AOvVaw0ju9hlm65NTTHiy-amoyKG

$\underline{\text { www.ejournal.ilkom.fisip-unmul.ac.id }}$ 